\title{
AUSÊNCIA DE PROTEÇÃO SOCIAL AOS MIGRANTES NO BRASIL EM TEMPOS DE PANDEMIA DA COVID-19 COM ENFOQUE NO DIREITO AO BENEFÍCIO ASSISTENCIAL DO AUXÍLIO EMERGENCIAL
}

\author{
ABSENCE OF SOCIAL PROTECTION TO MIGRANTS IN BRAZIL IN COVEN-19 \\ PANDEMIC TIMES WITH A FOCUS ON THE RIGHT TO ASSISTANCE BENEFIT
}

\section{AUSENCIA DE PROTECCIÓN SOCIAL A MIGRANTES EN BRASIL EN TIEMPOS DE PANDEMIA DE COVID-19 CON ENFOQUE EN EL DERECHO A ASISTENCIA BENEFICIO DE AYUDA DE EMERGENCIA}

Gina Vidal Marcílio Pompeu Pós-doutora pela Universidade de Lisboa

Universidade de Fortaleza (UNIFOR)

ginapompeu@unifor.br

Brasil

\section{Resumo}

O presente artigo tem o escopo de demonstrar a ausência de proteção social a que estão submetidos os migrantes no Brasil, no contexto da pandemia da Covid-19, com enfoque no direito ao auxílio emergencial, benefício de natureza assistencial, instituído pelo governo federal por meio da Lei 13.982 de março de 2020. Conclui-se que o Estado brasileiro não cumpre seu dever de proteção social aos migrantes no contexto da pandemia da Covid-19, que encontram-se invisíveis às políticas assistenciais de combate à pandemia.

Palavras chave: Migrantes. Covid-19. Ausência de Proteção Social. 


\begin{abstract}
It demonstrates the absence of social protection to which migrants in Brazil are subjected, in the context of the Covid-19 pandemic, with a focus on the right to emergency aid. There is an objection to access to the benefit motivated by the requirement for documents that culminates in the worsening of the condition of socioeconomic vulnerability. It is concluded that the Brazilian State is careless in its duty of social protection to migrants who are invisible to the assistance policies of the pandemic.
\end{abstract}

Keywords: Migrants. Covid-19. Absence of Social Protection.

\title{
Resumen
}

La falta de protección social para los migrantes en Brasil se demuestra en el contexto de la pandemia Covid-19 en relación al beneficio de la ayuda de emergencia. Existe una objeción al acceso al beneficio, motivada por la exigencia de documentos por parte de los organismos pagadores que muchos inmigrantes no tienen. Concluye por la negligencia del Estado en su deber de protección social al grupo que se ubica al margen de las políticas estatales para enfrentar la pandemia.

Palabras clave: Migrantes. COVID-19. Ausencia de protección social. 
disseminação da Covid-19,
doença causada pelo coronavírus
2, da síndrome respiratória aguda grave (SARS-CoV-2) assumiu proporções pandêmicas quando alastrou-se por mais de 180 países após o primeiro caso confirmado na província de Hubei, na China, em dezembro de 2019. Segundo dados da Organização Mundial da Saúde (OMS), aproximadamente 3.090 .34 pessoas foram infectadas pela doença, e, cerca de 217.769 casos evoluíram para óbito ${ }^{1}$. O Brasil, por ter confirmado 233.142 casos e aproximadamente 15.633 óbitos, até o dia 30 de maio de $2020^{2}$, inserem-se no rol de países com transmissão comunitária da Covid-19.

Nesse contexto, como meio de mitigar a transmissão viral no país, medidas extraordinárias foram implementadas pelos países afetados com o desígnio de proteger a coletividade. Nessa toada, na seara nacional, foram editadas, dentre outras, a Lei n. 13.979, de 06 de fevereiro de 2020 que dispõe de medidas para o enfrentamento da emergência de saúde pública de importância internacional, além do Decreto Legislativo n.6, de 20 de março de 2020, o qual reconhece

\footnotetext{
${ }^{1}$ Folha Informativa - Covid-19 (doença causada pelo novo coronavírus. Disponível em: https://www.paho.org/bra/index.php?option=com_content $\&$ view $=$ article $\& i d=6101:$ covid $19 \&$ Itemid $=875$. Acesso em: 01 de maio de 2020.

2 Coronavírus Brasil. Disponível em: https://covid.saude.gov.br/. Acesso em: 30 de maio de 2020.
}

o estado de calamidade pública em face da crise sanitária.

No âmbito regional, por sua vez, os Estados-membros, por meio de governadores e prefeitos, envoltos da decisão do Supremo Tribunal Federal $(\mathrm{STF})^{3}$ que reforça sua autonomia em observância ao princípio da separação dos poderes e baseando-se em critérios técnicos e científicos difundidos no âmbito nacional e internacional, implementaram medidas protetivas por intermédio de decretos executivos que determinaram, por exemplo; a paralisação de atividades econômicas não essenciais, distanciamento social, fechamento de fronteiras e até mesmo o lockdown, isolamento social obrigatório, como ocorreu no Estado do Maranhão, Pará, Ceará, entre outros.

Observa-se que, em face das medidas restritivas, a sociedade brasileira a qual possui $41,4 \%$ de sua população voltada para o trabalho informal, segundo o Instituto Brasileiro de Geografia e Estatística (IBGE) ${ }^{4}$, tem experimentado impactos socioeconômicos, sobretudo em relação aqueles dotados de maior vulnerabilidade socioeconômica. Com efeito, no sentido de atenuar os impactos da crise, a Lei n. 13.982

\footnotetext{
3 BRASIL. Ação Direta de Inconstitucionalidade n 6.341.

${ }^{4}$ Desemprego cai para $11,8 \%$ com informalidade atingindo maior nível da série histórica. Disponível em: https://censo2020.ibge.gov.br/2012-agencia-denoticias/noticias/25534-desemprego-cai-para-11-8-cominformalidade-atingindo-maior-nivel-da-seriehistorica.html. Acesso em: 01 de maio de 2020.
} 
de 2 de abril de 2020 e regulamentada pelo Decreto $\mathrm{n}^{\mathrm{o}} 10.316$, de 7 de abril de 2020, estabeleceu como medida excepcional de proteção social, o auxílio emergencial, benefício de renda básica emergencial, de natureza assistencial, a ser pago durante o período de 3 (três) meses direcionado aos trabalhadores informais, autônomos ou aos desempregados ${ }^{5}$.

Quando se remete à proteção social, sabe-se que é dever do Estado engendrar atenção especial às classes sociais menos favorecidas que é onde se inserem os migrantes, sejam na qualidade de imigrantes, de refugiados ou de apátridas ${ }^{6}$. Com o advento da Constituição Federal de 1988, promulgada sob a índole de defesa e valorização das garantias fundamentais, o estrangeiro adquire condições de igualdade de direitos em relação aos brasileiros. $\mathrm{Na}$ prática, contudo, constata-se que, em meio à pandemia da Covid-19, além do agravamento da condição de vulnerabilidade socioeconômica, muitos deles se encontram alijados do direito ao benefício assistencial, por motivos que vão desde a ausência de documentos exigidos pelas agências pagadoras, tanto para a efetivação do cadastro quanto para o pagamento do benefício, até a ausência de uniformização das agências

\footnotetext{
5 BRASIL. Lei no 13.982, de 2 de abril de 2020. Disponível em: http://www.planalto.gov.br/ccivil_03/_ato20192022/2020/lei/113982.htm. Acesso em: 01 de maio de 2020.
}

pagadoras em relação ao atendimento aos migrantes.

$$
\text { O cenário denota a indiferença e a }
$$
fragilidade do papel do Estado brasileiro no que tange ao dever de provisão social aos migrantes, sobretudo no contexto da pandemia do novo coronavírus, o que os sujeitam a condições desumanas e ilegais frente a ampla legislação nacional e internacional de proteção aos migrantes as quais o país é signatário. É importante mencionar que o benefício do auxílio emergencial se insere na seara do direito fundamental social à assistência aos desamparados, previsto nos artigos $6^{\circ} \mathrm{e}$ representa política social organizada pelo sistema de seguridade social no âmbito da assistência social, prevista no Art. 203 da Constituição Federal de 1988, a qual será prestado a quem dela necessitar, independente de contribuição.

É, portanto, um direito que objetiva propiciar de forma equânime, amparo, proteção, e capacitação aos desfavorecidos, sobretudo aqueles que se encontram fora do mercado de trabalho. Nessa conjuntura, indaga-se: Em que medida o Estado brasileiro que reconhece os migrantes como sujeitos de direito os situam às margens das ações de enfrentamento da pandemia da Covid-19 no

\footnotetext{
${ }^{6}$ É importante esclarecer que o termo migrante assenta-se no Art. $1^{\circ}$ §único do Decreto n. 9199 de 20 de novembro de 2019 que regulamenta a Lei 13.445 de 24 de maio de 2017.
} 
tocante ao direito fundamental à assistência social? Por que o Estado brasileiro é displicente no seu dever de proteção social aos migrantes na pandemia da Covid-20 e quais os efeitos causados?

Para responder aos questionamentos, analisa-se de início, a proteção normativa dos migrantes com ênfase na Declaração dos Direitos Humanos, no Pacto Internacional sobre Direitos Econômicos, Sociais e Culturais (PIDESC), nos Tratados e documentos regionais direcionados aos refugiados, como a Convenção de 1951 e o protocolo de 1967 e a Declaração de Cartagena, respectivamente, e na legislação nacional com esteio na Lei 13.445/2017 (Lei de Migração) e na Lei 9474/90 (Lei do Refúgio). Em seguida, contextualiza-se sua condição social com o atual fenômeno que os cercam, de modo a expor o dever de proteção social do Estado brasileiro com enfoque no direito à assistência social. Por fim, aborda-se a ausência de proteção por parte do Estado brasileiro no dever de assegurar o direito ao benefício social do auxílio emergencial ao grupo, suas causas e efeitos à pessoa migrante.

A metodologia assenta-se em estudo descritivo-analítico, desenvolvida por meio de pesquisa bibliográfica. Trata-se de pesquisa documental, na medida em que se

Declaração Universal dos Direitos Humanos. Disponível em: utiliza de artigos em revistas científicas indexadas relacionados ao tema. A pesquisa é de natureza teórica. Quanto à abordagem, a pesquisa classifica-se em qualitativa com as técnicas de análise documental, estatísticas e de revisão bibliográfica.

\section{Proteção normativa dos migrantes: da Declaração Universal dos Direitos Humanos à Lei 13445/2017}

A proteção normativa dos migrantes deriva dos direitos do homem, da luta pela humanidade para a consolidação dos direitos dos povos que, fundamentalmente, se constrói ao longo do tempo, desde a préhistória até a contemporaneidade. Parte-se da contemporaneidade no contexto do pósSegunda Guerra Mundial com a aprovação da Declaração Universal dos Direitos Humanos (DUDH) pela Assembleia Geral das Nações Unidas em 10 de dezembro de 1948, momento em que os Estados-membros firmam o compromisso de promover em cooperação com a Organização das Nações Unidas (ONU) e o respeito universal e efetivo dos direitos do homem e das liberdades fundamentais ${ }^{7}$.

A Declaração Universal dos Direitos Humanos inspira a elaboração de dois

https://www.ohchr.org/EN/UDHR/Documents/UDHR Translations/por.pdf. Acesso em: 05 de maio de 2020. 
importantes documentos que compõem a Carta Internacional dos Direitos Humanos, o Pacto Internacional dos Direitos Civis e Políticos (PIDESC) e o Pacto Internacional sobre os Direitos Humanos, ambos criados pela Assembleia Geral da ONU, em 16 de dezembro de 1966, sob o fundamento de assegurar a homens e mulheres igualdade no gozo de todos os direitos civil e políticos, econômicos, sociais e culturais enumerados nos pactos $^{8}$. É por meio do PIDESC que se reconhece, o direito de toda pessoa à previdência social e ao seguro social ${ }^{9}$.

Inspira-se ainda, a criação de tratados multilaterais destinados à proteção dos grupos mais vulneráveis da sociedade, como os refugiados, por exemplo. No tocante aos refugiados, especificamente, elabora-se a Convenção das Nações Unidas Relativa ao Estatuto dos Refugiados pela ONU, em 28 de julho de 1951, em Genebra, na Suíça, retificado, posteriormente, pelo protocolo de 31 de janeiro de 1967. O mencionado Tratado estabelece a definição de refugiado e dispõe sobre seus direitos e deveres. De forma paralela, por meio de uma ação conjunta de responsabilidade entre Estados da Europa, institui-se em 14 de dezembro de 1951, o Alto Comissariado das Nações Unidas para

8 ONU, Direitos Humanos. Disponível em: https://nacoesunidas.org/docs/direitoshumanos/. Acesso em: 05 de maio de 2020.

9 Pacto Internacional de Direitos Econômicos, Sociais e Culturais: Disponível em:

https://www.oas.org/dil/port/1966\%20Pacto\%20Internac ional $\% 20$ sobre $\% 20$ os $\% 20$ Direitos $\% 20$ Econ $\%$ C3\%B3m
Refugiados (ACNUR), entidade autônoma, desprovida de ideologia política, direcionada às ações de proteção aos refugiados.

De acordo com o artigo $1^{\circ}$ da Convenção de 1951, refugiado, portanto, é toda pessoa que, em razão de fundados temores de perseguição devido à sua raça, religião, nacionalidade, associação a determinado grupo social ou opinião política, encontra-se fora de seu país de origem e que, por causa dos ditos temores, não pode ou não quer fazer uso da proteção desse país ou, não tendo uma nacionalidade e estando fora do país em que residia como resultado daqueles eventos, não pode ou, em razão daqueles temores, não quer regressar ao mesmo ${ }^{10}$.

Os mecanismos apresentados representam marcos normativos do direito ao refúgio, que definem, tutelam, resguardam e propõem medidas de proteção, ou seja, os qualificam como sujeitos de direito (JUBILUT, 2007, p.27). É importante mencionar que, com a intensificação dos fluxos migratórios para países em desenvolvimento, amplia-se a necessidade de se criar mecanismos de proteção aos refugiados no âmbito regional, no sentido de estabelecer diretrizes e ações para a

icos, $\% 20$ Sociais $\% 20 \mathrm{e} \% 20 \mathrm{Culturais.pdf}$. Acesso em: 05 de maio de 2020.

10 Convenção Relativa ao Estatuto dos Refugiados. Disponível em: https://www.acnur.org/fileadmin/Documentos/portugues /BDL/Convencao_relativa_ao_Estatuto_dos_Refugiados .pdfAcesso em: 10 de maio de 2020 . 
consecução dos direitos dentro da realidade de cada país.

Nessa conjuntura, por meio de um simpósio acadêmico intitulado "Colóquio sobre Proteção Internacional dos Refugiados na América Central, México e Panamá: Problemas Jurídicos e Humanitários”, em Cartagena, na Colômbia, em 1984, elaborouse a Declaração de Cartagena, documento regional que, inspirado na Convenção da Unidade Africana para Refugiados em 1969, amplia a definição de refugiado ao acrescentar a violência generalizada dos direitos humanos e situações de grave perturbação da ordem pública como considerações para o reconhecimento do status de refugiado (BARRETO, 2010, p. 17) que foi aprovada, inclusive pela Assembleia Geral da OEA em $1985^{11}$.

Vale lembrar que o Brasil é signatário dos documentos internacionais mencionados uma vez que ratificou o Pacto Internacional de Direitos Econômicos, Sociais e Culturais (PIDESC) por meio do Decreto n. 591 de 06 de julho de 1991, ratificou ainda, a Convenção Relativa ao Estatuto dos Refugiados por meio do Decreto n. 99.757 de 1990, bem como assinou a Declaração de Cartagena, em 1984. É com base nos documentos internacionais que o Brasil torna-

\footnotetext{
${ }^{11}$ O Sistema Interamericano de Direitos Humanos. Disponível em:

https://www.mpma.mp.br/arquivos/COCOM/arquivos/cen tros_de_apoio/cao_direitos_humanos/direitos_humanos/te
}

se um país receptor de migrantes, com o compromisso de protegê-los de acordo com as diretrizes dos mencionados documentos.

No âmbito nacional, a proteção normativa surge com o advento da Constituição de 1988, em que o estrangeiro adquire condições de igualdade de direitos em relação aos brasileiros, conforme Art. $5^{\circ}$, caput. Portanto, ao estrangeiro no Brasil deve-se assegurar os direitos sociais previstos no Art. $6^{\circ}$ da Constituição de 1988, entre eles; o direito à saúde, educação, moradia, assistência aos desamparados, entre outros. Soma-se a isso, o fato de que, em 1997, alicerçado nos dispositivos da Convenção de 1951 e o protocolo de 1967 , bem como na Declaração de Cartagena, o Brasil sancionou a Lei n. ${ }^{\circ}$ 9.474/97 - Lei do Refúgio (APOLINÁRIO; JUBILUT, 2008, p.29).

Nos termos da Lei 9747/97, com esteio da Convenção de 1951 e na Declaração de Cartagena, refugiado é toda pessoa que, em razão de fundados temores de perseguição por motivos de raça, religião, nacionalidade, grupo social ou opiniões políticas, encontrese fora de seu país de nacionalidade, bem como aqueles que, devido a grave e generalizada violação dos direitos humanos, são obrigados a deixar seu país de nacionalidade para buscar refúgio em outro

xtos/sistemaInteramericano.htm. Acesso em: 05 de maio de 2020 . 
país ${ }^{12}$. Percebe-se portanto, que a definição de refugiado aperfeiçoa-se no tempo de acordo com as necessidades que surgem ao longo dos anos e que tornam-se essenciais para o reconhecimento e proteção social.

Com a intensificação de fluxos migratórios para o Brasil a partir do ano de 2010, torna-se imprescindível a criação de uma legislação específica adequada aos princípios constitucionais brasileiros $\mathrm{e}$ documentos internacionais, com o propósito de reconhecê-los como sujeitos de direitos e de titulares de garantias fundamentais. Nessa toada, sanciona-se a Lei 13.445 de 24 de maio de 2017 intitulada Lei de Migração. A lei 13.445/2017 adveio ainda da necessidade de se revogar o Estatuto do Estrangeiro, Lei $\mathrm{n}^{\circ}$ 6.815 , de 19 de agosto de 1980, criada no período da Ditadura Militar (1954 - 1985), inspirada na doutrina da segurança nacional que via o imigrante como uma espécie de ameaça ao país.

Trata-se de legislação ampla de migrantes, a qual alcança o imigrante, categoria onde se insere os refugiados, o emigrante, os visitantes, os residentes fronteiriços e até os apátridas. Dispõe sobre os direitos e os deveres do migrante e do visitante, regula a sua entrada e estada no País e

\footnotetext{
${ }^{12}$ BRASIL. Lei Federal n. 9474 de 22 de julho de 1997. Define mecanismos para a implementação do estatuto dos refugiados de 1951, e determina outras providências Disponível em:

http://www.planalto.gov.br/ccivil_03/leis/19474.htm. Acesso em: 23 de maio de 2020.
}

estabelece princípios e diretrizes para as políticas públicas a serem implementadas. Vale ressaltar que a Lei 13.445/2017 reforça o preceito constitucional de igualdade de direitos em relação aos brasileiros e estabelece no Art. $3^{\circ}$, XI, como diretriz da política migratória, o acesso igualitário e livre do migrante a serviços, programas e benefícios sociais, bens públicos, educação, assistência jurídica integral pública, trabalho, moradia, serviço bancário e seguridade social ${ }^{13}$.

Em face das considerações, tem-se que, em face da proteção normativa desde a Declaração Universal de Direitos Humanos no âmbito global até a elaboração da Lei 13445/2017 no âmbito nacional, considerase os migrantes sujeitos de direito e titulares de garantias fundamentais. Representa, portanto, o compromisso que o Estado brasileiro protegê-los, sobretudo em tempos de crise. É nesse contexto que passa-se a analisar o dever de proteção social na atual conjuntura da pandemia da Covid-19, notadamente no que concerne ao direito à assistência social com enfoque no benefício assistencial do auxílio emergencial.

\footnotetext{
${ }^{13}$ BRASIL. Lei Federal n.13445/2017 de 24 de maio de 2017. Institui a Lei de Migração. Disponível em: http://www.planalto.gov.br/ccivil_03/_ato20152018/2017/lei/113445.htm. Acesso em: 05 de maio de 2020.
} 


\section{O dever de proteção social do estado brasileiro no âmbito do direito à assistência social}

Abordar sobre proteção social numa sociedade, faz-se necessário, remontar-se ao estado de natureza exposto por Thomas Hobbes em sua obra Leviatã, que representa um Estado sem direito, sem leis, sem constituição política e sem instituições sociais, onde os indivíduos são entregues a si mesmos e, portanto, são concorrentes numa concepção de guerra de todos contra todos. Trata-se, de uma sociedade de total insegurança onde os homens vivem sob o signo da ameaça, porque não detém em si mesmos o poder de proteger e proteger-se (CASTEL, 2005, p.8).

Para o autor, dessa conjuntura surge a necessidade de delimitar-se uma proteção aos indivíduos como imperativo categórico para a convivência numa sociedade denominada sociedade de segurança, que para ele, representa a condição primordial para que os indivíduos possam "fazer sociedade". A existência de um Estado protetor em Hobbes representa único meio de garantir esta segurança que se consolida com a renúncia da liberdade dos indivíduos ao Estado absoluto. Hobbes expõe, ainda, sobre a necessidade de uma proteção social do Estado aos indivíduos necessitados.
O autor expõe que muitos indivíduos numa sociedade, em face de circunstâncias imprevisíveis, tornam-se incapazes de prover seu próprio sustento, todavia essas pessoas não devem ser esquecidas à caridade privada. É do Estado o dever de providenciar em toda medida as necessidades desses indivíduos (HOBBES, 1983 p.115). O ideal de proteção social no Brasil se consolida com o advento da Constituição Federal de 1988, sob o propósito de assegurar o exercício dos direitos sociais, individuais, a liberdade, a segurança, o bem estar, a igualdade e a justiça como valores de uma sociedade fraterna, pluralista e sem preconceitos.

Nessa ótica, portanto, ao passo que a Constituição Federal garante direitos, atribuise ao Estado o dever de implementá-los por meio de pressupostos materiais e necessários para consecução, uma vez que efetivar direitos sociais requer destinação orçamentária (POMPEU, 2019, p.229). O dever de proteção social por parte do Estado, portanto, depende de prestações positivas que garanta aos cidadãos o alcance de um patamar mínimo civilizatório por meio da efetivação dos direitos sociais. Isso porque os direitos sociais são considerados direitos públicos subjetivos e de segunda dimensão, que têm aplicação imediata, e necessita-se, portanto, da execução de políticas públicas para a sua implementação (COMPARATO, 2010, p.206). 
Nas palavras de Robert Alexy, podese dizer que, é por intermédio de uma relação triádica entre o titular de direito fundamental, o Estado e uma ação estatal positiva, que são concretizados os direitos sociais que compõem o sistema de proteção social (ALEXY, 2011, p.445). Por meio dessa conjuntura, analisa-se o dever de proteção social do Estado no âmbito do direito fundamental à assistência aos desamparados que compõe o artigo $6^{\circ}$ da Constituição Federal de 1988. Desdobra-se em política social, a que a Constituição brasileira denominou de assistência social, prestada a quem dela necessitar, independente de contribuição, conforme previsão em seus Arts. 203 e 204.

Cumpre ressaltar, portanto, que cuidase de uma norma constitucional tipicamente programática e de eficácia limitada na medida em que depende da organização e funcionamento de serviços públicos específicos, os quais exigem além da disciplina normativa de nível infraconstitucional, a destinação de recursos orçamentários e a estruturação material da atividade estatal (RAMOS, 2007, p.342). Ressalta-se ainda que, é por meio do Sistema de Seguridade Social, que compõe da Ordem Social, constante nos artigos 194 e 195 do

\footnotetext{
${ }^{14}$ Lei n. 8742 de 7 de janeiro de 1993. Disponível em: http://www.planalto.gov.br/ccivil_03/leis/18742.htm. Acesso em: 05 de maio de 2020.
}

mesmo diploma, que o direito à assistência social é organizado.

O sistema compreende um conjunto integrado de ações de iniciativa dos poderes públicos e da sociedade, destinadas a assegurar, além da assistência social, direitos relativos à saúde e à previdência social. A assistência social é regulamentada pela Lei $\mathrm{n}^{\circ}$ 8.742, de 7 de dezembro de 1993, intitulada Lei Orgânica de Assistência Social (LOAS) que tem como finalidade provê os mínimos sociais à população mais vulnerável ${ }^{14}$. Salienta-se que a assistência social representa um direito do cidadão a ser concretizado pelo Estado que objetiva viabilizar, de forma equânime, a autonomia individual necessária ao exercício qualificado da cidadania de pessoas que, apesar de materialmente excluídas, devem ser reconhecidas, a todo o momento, como livres e iguais (CHAVES, 2013, p. 16).

Isso se faz com observância ao princípios da supremacia do atendimento às necessidades sociais, da universalização dos direitos sociais, o respeito à dignidade do cidadão, igualdade de direitos no acesso ao atendimento e a divulgação ampla dos benefícios, serviços, programas e projetos assistenciais, bem como dos recursos oferecidos pelo Poder Público e dos critérios para sua concessão. Em tempos de crise, a 
circunstância de vulnerabilidade socioeconômica das classes menos favorecidas tende a agravar-se. Nesse momento, o Estado deve direcionar uma atenção especial com o intuito de mitigar os impactos socioeconômicos oriundos da crise.

No atual contexto da pandemia da Covid-19 no Brasil, por meio da Medida Provisória n. 937 de 2 de abril de 2020, determinou-se a abertura de crédito extraordinário para fins de auxílio emergencial destinado às pessoas em situação de vulnerabilidade ${ }^{15}$. É sob o fundamento da igualdade de direitos entre brasileiros e estrangeiros que também deve-se assegurar proteção social aos migrantes, principalmente aos refugiados onde a condição de vulnerabilidade socioeconômica é mais acentuada. Nesse mesmo sentido, a Lei 13445/17 - Lei de Migração - no Art. 3º, inciso $\mathrm{X}$, garante acesso igualitário e livre do migrante, a serviços, programas e benefícios sociais, bens públicos, educação, assistência jurídica integral pública, trabalho, moradia, serviço bancário e seguridade social ${ }^{16}$.

Vale salientar que a condição de vulnerabilidade social advém do panorama da desigualdade social de um país. No Brasil, por

\footnotetext{
${ }^{16}$ Lei 13.445/2017 de 24 de maio de 2017. Lei de Migração. Disponível em: http://www.planalto.gov.br/ccivil_03/_ato20152018/2017/lei/113445.htm. Acesso em: 05 de maio de 2020.

${ }^{17}$ Condições de vida, desigualdade e pobreza. Disponível em:
}

exemplo, segundo dados do IBGE, aproximadamente 13,5 milhões pessoas sobrevivem com renda mensal per capita inferior a $\mathrm{R} \$ 145$, ou U\$S 1,9 por dia, critério adotado pelo Banco Mundial para identificar a condição de extrema pobreza ${ }^{17}$. Nesse mesmo sentido, de acordo com a pesquisa realizada pelo Programa das Nações Unidas para o Desenvolvimento (PNUD) em 2018, cerca de $25 \%$ da população brasileira vive abaixo da linha da pobreza e a parcela dos $10 \%$ mais ricos no país, concentra o percentual de $42 \%$ da renda total do país ${ }^{18}$, apesar do país ocupar a $8^{\mathrm{a}}$ posição em crescimento econômico.

Nessa linha de pensar, infere-se que a condição de vulnerabilidade social representa característica peculiar àquelas pessoas que vivem às margens das políticas públicas estatais que é onde se inserem os migrantes. Os migrantes, especialmente, os refugiados, além de desprotegidos do país de origem, pois na maioria das vezes é o próprio responsável pelas violações de direitos, essa condição geralmente persiste no país receptor, sobretudo naqueles que são periféricos ao capitalismo, onde a desigualdade e a exclusão são fenômenos que se cruzam a todo instante,

https://www.ibge.gov.br/estatisticas/multidominio/condico es-de-vida-desigualdade-e-pobreza.html. Acesso em: 05 de maio de 2020.

${ }^{18}$ Relatório do Desenvolvimento Humano 2019. Disponível em: http://hdr.undp.org/sites/default/files/hdr_2019_pt.pdf. p. 108. Acesso em: 05 de maio de 2020. 
como é o caso do Brasil, por exemplo (SANTOS, 2010, p. 282).

No contexto de atual pandemia da Covid-19, os migrantes encontram-se situados às margens das políticas estatais de enfrentamento da doença. Isso porque uma parcela significativa deles encontra-se alijadas do direitos ao benefício assistencial do auxílio emergencial. Em que pese existir a igualdade de direitos em relação aos brasileiros, na prática essa igualdade apresenta-se de forma mitigada e o Estado brasileiro encontra-se em débito com seu dever de proteção social ao grupo. O dever de proteção social deriva da necessidade de se garantir um patamar mínimo civilizatório aos cidadãos e o não cumprimento por parte do Estado, leva-se a questionar a legitimidade da democracia.

Nesse sentido, passa-se a contextualizar, sob os fundamentos apresentados, a problemática enfrentada pelos migrantes no que se refere o acesso ao benefício assistencial do auxílio emergencial.

\section{A problemática do acesso ao benefício assistencial do auxílio emergencial pelos migrantes}

\footnotetext{
${ }^{19}$ CPF vira obstáculo para imigrante pedir auxílio emergencial. Disponível em: https://www.migramundo.com/cpf-vira-obstaculo-para-
}

Constata-se que em meio à pandemia da Covid-19, além do agravamento da condição de vulnerabilidade socioeconômica, os migrantes se encontram alijados do direito ao benefício assistencial do auxílio emergencial, seja no âmbito da solicitação, seja na esfera recebimento do benefício junto às agência pagadoras. Isso se justifica pela exigência de documentação tanto para a solicitação do benefício, para a qual exige-se o Cadastro de Pessoa Física (CPF), quanto para seu recebimento, em que se exige-se documento válido com foto, como por exemplo, o Documento Nacional Migratório (DNM), o Registro Nacional de Estrangeiros (RNE), ou a Carteira de Trabalho e Previdência Social (CTPS) para o pagamento presencial $^{19}$.

Vale ressaltar que nem todos os migrantes, principalmente os solicitantes de refúgio, dispõe da documentação exigida, seja em face de pendência na decisão de solicitação de refúgio, seja em razão do prazo de validade dos documentos, seja pela própria condição social a que se encontram, por não disporem de ferramentas tecnológicas, como computadores ou smartphones, por exemplo, necessários à solicitação do auxílio. Soma-se a isso, a barreira do idioma que também dificulta $\mathrm{o}$ acesso às informações sobre $\mathrm{o}$

imigrante-pedir-auxilio-emergencial-veja-comoregularizar-o-documento/. Acesso em: 09 de maio de 2020. 
procedimento para o acesso ao auxílio emergencial.

Além disso, é importante mencionar a ausência de uniformização na exigência da documentação por parte das agências pagadoras. Para umas agências é imprescindível apresentação do comprovante de solicitação de refúgio quando se trata de refugiados e para outras, é indispensável a apresentação da Carteira de Trabalho e Previdência Social quando se trata de imigrantes econômicos. Foi com base nessa problemática que a Defensoria Pública da União (DPU) ajuizou Ação Civil Pública de n. 5007915-28.2020.4.03.6100 com pedido liminar em face do Banco Central e a Caixa Econômica Federal, para que seja garantido o pagamento do auxílio emergencial aos migrantes, independentemente da situação migratória e de documentação com validade expirada.

Segundo a DPU, uma quantidade significativa de migrantes está potencialmente impedida de acesso ao benefício por questões puramente operacionais, derivadas da insuficiente normatização ou implantação da política pela parte ré. $\mathrm{Na}$ ação esclarece que a referida verba tem caráter assistencial e enquadra-se como direito fundamental, ante seu papel na segurança alimentar e saúde da população.

\footnotetext{
${ }^{20}$ Ação Civil Pública Cível n. 5007915-28.2002.4.03.6100. Disponível em:

file:///C:/Users/Usuario/Downloads/ACP\%20auxi\%CC\%8
}

Assim, além dos brasileiros, os estrangeiros residentes no país, por força do art. $5^{\circ}$, caput da Constituição da República fazem jus ao benefício assistencial. Deve-se recordar, ainda, que a Lei de Migração, garante o direito à assistência social que abrange, portanto, auxílio-emergencial ${ }^{20}$.

Assinala-se, ainda, que a natureza do benefício é alimentar e os migrantes, nesse contexto, por se situarem às margens das ações estatais da Covid-19, sobrevivem da solidariedade, da caridade e de ações voluntárias que promovem a distribuição de cestas básicas. A negação desse direito compromete o mínimo existencial, os expõe à condições desumanas e ilegais, viola o direito fundamental à assistência social e ofende a dignidade da pessoa humana, fundamento reitor da República Federativa do Brasil e critério material por excelência dos direitos fundamentais sociais, que tem o condão de promover um patamar de igualdade entre os seres humanos. (OLSEN, 2006, p. 34).

Diferentemente do Estado brasileiro, outros países, como Portugal, por exemplo, promoveu a regularização temporária dos migrantes com processos migratórios pendentes por meio do Despacho n. ${ }^{\circ} 3863-$ B/2020 da Presidência do Conselho de Ministros, Administração Interna, Trabalho, no sentido de garantir inequivocamente os 
direitos de todos os cidadãos estrangeiros com processos pendentes no Serviço de Estrangeiros e Fronteiras, no âmbito da Covid-19. Em que pese o caráter temporário da medida, demonstra-se a preocupação do país para com as pessoas migrantes ${ }^{21}$.

As circunstâncias apresentadas denotam a indiferença do Estado brasileiro em relação aos migrantes no contexto da pandemia da Covid-19 e depreende-se que o país caminha em sentido oposto à própria legislação nacional migratória e aos tratados internacionais ratificados, tanto é que retirouse do Pacto Global de Migração Segura, Ordenada e Regular ${ }^{22}$, instituído em dezembro de 2018 no Marrakesh, ratificado pela ONU e assinado por 164 países, incialmente, inclusive pelo Brasil em seu governo anterior ${ }^{23}$, após sua inclusão entre as metas da Agenda 2030 - Objetivos do Desenvolvimento Sustentável (ODS) para erradicar a pobreza, reduzir as desigualdades sociais, promover crescimento econômico inclusivo e o bem estar a todos por meio de instituições eficazes ${ }^{24}$.

Demonstra-se, portanto, por meio da problemática apresentada que é a objeção na aprovação e concessão do benefício

\footnotetext{
${ }^{21}$ Despacho n. $^{\text {o } 3863-B}$ de 27 de março de 2020. Presidência do Conselho de Ministros, Administração Interna, Trabalho. Disponível em: https://dre.pt/application/conteudo/130835082. Acesso em: 11 de maio de 2020.

${ }^{22}$ Documento dissociação do pacto Global para Migração Segura, Ordenada e Regular da ONU. Disponível em: file:///C:/Users/Usuario/Desktop/Disserta\%C3\%A7\%C3\%
}

assistencial do auxílio emergencial, a medida na qual os migrantes encontram-se invisíveis ao olhos do Estado brasileiro no tocante às ações de enfrentamento da pandemia da Covid-19. Passa-se a analisar a ausência do dever de proteção social estatal à pessoa migrante nesse contexto e seus efeitos.

\section{A ausência do dever de proteção social estatal aos migrantes no tocante ao benefício assistencial do auxílio emergencial e seus efeitos}

A dificuldade de acesso ao benefício assistencial do auxílio emergencial demonstra a displicência do Estado brasileiro para com seu dever de proteção social. Os motivos desdobram-se numa dimensão multifacetada. Primeiramente, salienta-se que a dificuldade de acesso ao benefício torna pública a indiferença disfarçada de uma certa intolerância por parte do país aos migrantes, mesmo sob o manto de ampla legislação as quais os reconhecem como sujeitos de direito e titulares de garantias fundamentais.

Nessa linha de pensar, infere-se do pensamento de Zigmum Bauman que a

\footnotetext{
A3o/Dissocia\%C3\%A7\%C3\%A3o-Brasil-do-GCM.pdf. Acesso em: 11 de maio de 2020.

${ }^{24}$ Nações Unidas do Brasil. 17 objetivos para transformar nosso mundo. Disponível em: https://nacoesunidas.org/pos2015/agenda2030/. Acesso em: 12 de maio de 2020 .
} 
displicência do Estado brasileiro representa o que o autor titula de globalização da indiferença, que nada mais é que uma política de lavar as mãos e pensar que o problema migratório não é do país. A ideia do autor assenta-se na seguinte frase: "Isso não me afeta, não me preocupa, não é da minha conta" (BAUMAN, 2016, p.26). Salienta-se que essa indiferença provoca impactos econômicos aos migrantes, uma vez que a ausência de renda dificulta o acesso a recursos materiais necessários à própria sobrevivência, principalmente em tempos da pandemia da Covid-19.

Em segundo lugar, sob as influências do neoliberalismo, presencia-se no Brasil um Estado regulador da atividade econômica o qual se vincula a possibilidades orçamentárias para a consecução dos direitos e, portanto, ocupa posição de recuo para com seu dever de proteção social. As decisões tomadas por esse modelo estatal traçam políticas públicas voltadas para os setores da economia com pouca ou nenhuma preocupação com a questão dos impactos sociais, seus entendimentos são tecnocratas, esquecendo que políticas públicas envolvem a ponderação dos efeitos sociais na população (BELLO, BERCOVICI E LIMA 2019, p. 1787)

Por essa razão, vive-se num contexto de intensa desigualdade social no país com um percentual de $25 \%$ da população que vive abaixo da linha da pobreza, além de alta concentração de renda, precarização das condições de trabalho, entre outras agravantes, pelas quais demonstram de forma clara a displicência estatal na efetivação de direitos sociais. Além da desigualdade social, presencia-se ainda, a precarização das condições de trabalho, discursos de ódio, intolerâncias, negação do outro, recrudescimento de políticas repressivas e opressoras as quais leva-se a crer que vive-se num contexto em que as democracias estão sendo desmascaradas pelas suas incapacidades de efetivar direitos, os quais foram duramente conquistados ao longo da história (IGREJA, CAMACHO, DANTAS, RAMPIM, 2018, p.1).

Reportar-se à assistência social, que é política pública, dever do Estado e direito de cidadania, torna-se mais evidente $\mathrm{o}$ desinteresse na efetiva proteção social por parte do Estado. Isso porque a assistência social antes de tornar-se política pública que ocorreu apenas com a Constituição Federal de 1988, desenvolvia-se por meio de instituições não governamentais sob a influência da filantropia e da caridade, ou seja, sob o manto do favor. Essas influências ainda persistem nesta seara e justificam as palavras de Maria Berenice Corjas de que a assistência social é irmã siamesa do assistencialismo (COUTO, 2015, p. 670).

Portanto, a essência do direito à assistência social representa o terceiro motivo 
exposto que culmina na falta de interesse do Estado em consolidar esse direito sob um viés transformador. É nesse sentido que expõe Maria Carmelita Yazbeck sobre a assistência social. Para a autora, dissociar-se assistência social do assistencialismo e filantropia representa desafios. $\mathrm{O}$ clientelismo consolidou-se numa cultura tuteladora que não tem favorecido o protagonismo e nem a emancipação dos usuários da assistência social na nossa sociedade em razão de ter sido apoiada por décadas na matriz do favor, do apadrinhamento e do clientelismo (YAZBECK, 2004, p.19).

Depreende-se, portanto, que os motivos apresentados geram efeitos aos migrantes, tanto no âmbito econômico, pois os privam da aquisição de bens necessário à sobrevivência em meio à crise, quanto no âmbito moral, de modo que, a inexistência de proteção social denota ausência de reconhecimento, gera sentimento de insegurança e provoca, conforme discurso de Giorgio Agamben, o silenciamento do sujeito, que está diretamente associado à ideia de anulação do indivíduo da sociedade (AGAMBEN, 2008, p.58). Vale mencionar que a anulação do indivíduo, por si só, causa uma identidade marcada pela autodegradação, pela privação de direitos e pela baixa autoestima que representam um sofrimento de indeterminação. (HONNETH, 2007, p.53).
A falta de interesse por parte do Estado em efetivar o direito à assistência social sob um viés transformador, subleva-se ao discurso de Ferdinand Lassalle. Para o autor, questões constitucionais são políticas e não jurídicas, ou seja, emerge-se do poder. A normatividade, portanto, sujeita-se à realidade, aos fatores reais do poder, de modo que, quando isso não ocorre, as constituições e as leis de um país apresentam-se num sentido figurado, ao que ele denomina de mera folha de papel. (LASSALLE, 2003, p.40). No mesmo sentido, faz-se importante abordar-se o discurso de Linn Hunt, ao que dela denomina de direitos humanos em sociedade.

Para a autora os direitos humanos no interior de uma sociedade só se tornam significativos quando ganham conteúdo político e devem ser naturais, ou seja, inerentes aos seres humanos, iguais e universais, que quer dizer, aplicáveis por toda parte (HUNT, 2007, p.11). Trata-se de direitos a serem assegurados no mundo político secular que requerem participação ativa daqueles que os detém, porém, na atualidade, passa-se a questionar o critério da igualdade e da universalidade numa sociedade que exclui pessoas, que anula o sujeito, que dificulta o acesso aos direitos como o Brasil, por exemplo.

$$
\text { É imperioso destacar ainda, o }
$$
pensamento de Hannah Arendt no tocante à 
cidadania. Para a autora, a cidadania advém da ordem política e representa, o direito a ter direitos, que por sua vez, além de declarados, devem ser concretizados, pois correspondem aos direitos dos seres humanos que se constroem da convivência coletiva e eclodem no acesso a um espaço público comum (ARENDT, 1989, p.332). Desse modo, questiona-se a expressão, direito a ter direitos no cerne de um Estado que ocupa posição de recuo para com seu dever de proteção social.

Importa mencionar as palavras de Cass e Holmes na obra The Cost of Rigths: Why liberty dependes on taxes, de que as necessidades são infinitas, ao passo que os recursos públicos são finitos (CASS e HOLMES, 1999, p.94). Da afirmação, depreende-se que para a consecução de direitos sociais, exige-se planejamento orçamentário e estratégias no âmbito das políticas públicas para que os direitos possam ser levados a sério, de forma a conciliar o crescimento econômico com o desenvolvimento humano e o Estado brasileiro, diante das premissas constitucionais, é o responsável pelas ações destinadas ao crescimento econômico, desenvolvimento humano e proteção social.

Nesse sentido, o que se busca, portanto, embasa-se num ideal de justiça social que não se encerra apenas com critério material, ou seja, apenas com a concessão do benefício assistencial aos migrantes, pois o próprio Art. 203 da Constituição Federal de 1988, que dispõe sobre à assistência social, numa leitura contextualizada, não delimita apenas critério material em seus objetivos. Busca-se uma justiça social que assenta-se no discurso de Amartya Sen, a qual classifica o cidadão como agente ativo na sociedade.

A condição de agente é uma característica peculiar na identidade e no agir do ser humano que se entende como membro de uma sociedade, além de ser o responsável pelos seus destinos, que o qualifica como impulsionador do processo de organização e de desenvolvimento do ambiente onde se encontra (ZAMBAM, KUJAWA 2017, p. 85). Nas palavras dos autores, a condição de agente preserva a dignidade da pessoa e sublinha a opção pela orientação prioritária das políticas públicas a partir do capital humano, pois ao passo que o cidadão possui direitos inalienáveis, o Estado tem o dever de garanti-los por meio de sua ampla estrutura de instituições, recursos, legislação e outras organizações ou acordos.

Vale ressaltar que o discurso de Amartya Sen sobre privação de bens não se restringe a indicadores econômicos apenas, embora para ele o critério da renda se apresente de forma essencial no sentido de se evitar à pobreza. A privação de bens representa a agrura de não poder exercer o que ele denomina de liberdades substantivas, isto é, de exercer a condição de agente ativo 
na sociedade, e de desenvolver as capacidades básicas inerentes a cada indivíduo (SEN, 2008, p. 175). Para Sen, a ideia de justiça social foca-se em realizações, sua pretensão é valorizar a vida dos cidadãos e seu intento está em encontrar razões que justifiquem a distância existente entre justo e injusto, sob uma visão prática e realista do mundo (PANSIERI, 2016, p. 4).

A teoria de justiça de Amartya Sen afasta-se da teoria de Justiça como equidade de Jonh Rawls, a qual apresenta-se numa concepção embasada nos princípios da liberdade e da igualdade, pelos quais o Estado deve garantir bens primários de forma justa para os cidadãos que são livres e iguais. Para Amartya Sen, a teoria de justiça de Rawls nada mais é que uma justiça baseada em arranjos, a que ele denomina de institucionalismo transcendental, que se apega a um aspecto muito frágil da igualdade, quando aborda apenas os chamados bens primários $^{25}$. Nesse sentido, para Sen, deslocar-se o centro da análise da renda para os bens primários é um artifício, assim como analisar a pobreza sobre a égide da renda também constitui um artifício.

O autor defende um olhar direcionado à liberdade efetiva das pessoas de realizarem seus próprios projetos. Para Wayne Morrison a justiça como equidade de Rawls compara-

\footnotetext{
${ }^{25} \mathrm{Em}$ Teoria da Justiça, o autor aponta direitos, liberdades e oportunidades, assim como renda e riqueza e as bases
}

se com a divisão de um bolo de tamanho fixo e um determinado número de pessoas, o que para ele mostra-se insuficiente para retratar a sociedade (MORRISON, 2006, p. 472). Logo, a distribuição de justiça em uma sociedade com desigualdades profundas é tarefa muito mais ampla e pormenorizada, sendo necessário vencer resistências de todas as ordens possíveis, tradicionais, culturais, econômicas, entre outras (PANSIERI, 2016, p. 22).

Martha Nussbaum utiliza a abordagem das capacidades como garantias humanas centrais a serem asseguradas e implementadas pelo Estado, como um mínimo necessário à dignidade humana. $\mathrm{O}$ enfoque das capacidades de Nussbaum representa o pano de fundo de sua teoria de justiça social. O foco de sua abordagem são as capacidades humanas, em que as pessoas são capazes de fazer e serão instruídas pela ideia intuitiva de uma vida apropriada à dignidade humana. Trata-se, de uma explicação do mínimo de garantias sociais centrais compatíveis com diferentes visões sobre como lidar com questões de justiça e distribuição (NUSSBAUM, 2013, p.91).

Pretende-se, portanto, uma justiça social com o olhar inclusivo aos migrantes, com oportunidades sociais adequadas onde eles possam moldar o seu próprio destino. A

sociais do autorrespeito como bens primários (RAWLS, 2008, p. 536) 
justiça social que almeja-se não se finda com a concessão do benefício assistencial do auxílio emergencial aos migrantes sob uma ótica de que possuem status de beneficiários passivos de engenhosos programas de renda, como expõe Amartya Sen. A ideia transcende uma teoria de justiça focada no institucionalismo transcendental de Jonh Rawls, para uma teoria de justiça social focada em realizações que reconheça o papel positivo da condição de agente livre e sustentável e até mesmo o papel positivo da impaciência construtiva (SEN,2011, p.26).

Portanto, o dever de proteção social que o Estado deve cumprir a todos indistintamente tem o condão de garantir um patamar mínimo civilizatório aos cidadãos por meio do desenvolvimento de suas capacidades, sob pena de não ser considerado um Estado democrático. Nesse sentido, Gina Pompeu expõe que a ausência desse dever de proteção social, ou seja, de garantia e eficácia dos direitos fundamentais sociais, faz com que o país em débito com a democracia, pois de acordo com a autora não se fala em democracia quando parte da população não dispõe desses direitos, entre eles, a alimentação, educação, saúde, trabalho, moradia e quando se constata o desamparo, a fome e o abandono (POMPEU, 2019, p. 235).

Em face das considerações, tem-se que a indiferença do Estado brasileiro para com os migrantes, a qual enseja à ausência do dever de proteção social, apresenta-se numa dimensão multifacetada, como exposto anteriormente. A indiferença a que os tornam invisíveis às política de enfrentamento à pandemia da Covid-19, um Estado regulador da atividade econômica que se vincula a possibilidades orçamentárias para a consecução dos direitos e um direito que permanece com influência da filantropia e da caridade e que caminha a passos lentos para sua consolidação no país representam os possíveis motivos pelos quais os migrantes encontram-se invisíveis às políticas públicas, sobretudo no contexto da pandemia da Covid19.

Os efeitos da indiferença e da invisibilidade ensejam a exclusão social, a qual contribui para o aumento da desigualdade no país. Enseja ainda efeitos destrutivos aos migrantes por atingir sua autoestima, sua honra, por sentirem-se desacreditados de seu próprio potencial e portanto, incapazes de tornar-se agentes produtivos na sociedade. Vale lembrar que muitos dos migrantes, especificamente os venezuelanos na qualidade de refugiados, possuem um grau de escolaridade superior à do brasileiro, segundo pesquisa da Fundação 
Getúlio $\operatorname{Vargas}^{26}$ porém, em face da dificuldade que o país impõe em revalidar seus diplomas, a oportunidade de exercerem seus ofícios torna-se inviável e o trabalho informal, na maioria das vezes é a solução.

O Brasil por ser um país que se desenvolveu com participação significativa de migrantes, tem o dever de protegê-los, mas sob o viés de uma justiça social focada em realizações. Todavia, o que se tem são políticas de arranjos, e muitas vezes nem isso. Não se trata a invisibilidade dos migrantes no contexto da pandemia da Covid-19 como um caso isolado. Há tempos a ausência de proteção social por parte do Estado brasileiro, principalmente, em relação à integração social dos migrantes.

É certo que há políticas públicas direcionadas aos migrantes em Estados onde há maior como no Estado de São Paulo e Roraima, por exemplo, porém são insuficientes para assegurar a todos um patamar mínimo civilizatório. Depreende-se do contexto, que os sentimentos de empatia e práticas de alteridade não se fazem presentes por parte do próprio Estado brasileiro, de modo que muitos dos migrantes em meio a pandemia da Covid-19 estão a depender da

\footnotetext{
${ }^{26}$ FGV. Fundação Getúlio Vargas. Desafio Migratório em Roraima: repensando a política e gestão da migração no Brasil. Policy Paper - Imigração e Desenvolvimento. FGV DAPP. Rio de Janeiro. 2018. Disponível em: http://bibliotecadigital.fgv.br/dspace/bitstream/handle/104 38/24197/Desafio-migrato\%cc\%81rio-Roraima-policypaper.pdf?sequence=1\&isAllowed=y. p. 4. Acesso em: 19 de maio de 2020.
}

distribuição de cestas básicas por parte da sociedade para sobrevivência ${ }^{27}$.

Conclui-se que o Estado brasileiro é displicente no seu dever de proteção social aos migrantes. A ausência do Estado na organização da sociedade, sedimenta e amplia o fosso das desigualdades e outras disparidades e a sua interferência exclusivamente assistencialista ou de controle social, político e econômico impede outras dimensões integradas ao valor e exercício da liberdade (ZAMBAM, KUJAWA 2017, p. 70). Propõe-se, portanto, o acesso de forma facilitada ao auxílio emergencial pelos migrantes com a apresentação de qualquer documentação a que possuam, ainda que com prazo de validade expirado, sem exigência de foto, bem como a orientação às agências pagadoras para que o atendimento ocorra de modo uniformizado, haja vista a diferença na exigência da documentação por parte das agências.

O acesso ao benefício assistencial do auxílio emergencial pelos migrantes não assenta-se num ideal de justiça social de arranjos institucionais que os considerem apenas beneficiários passivos de programas de renda. A essência do acesso ao benefício é

\footnotetext{
${ }^{27}$ Organizações se mobilizam na doação de cestas básicas para imigrantes e refugiados durante a pandemia da Covid19. Disponível em: https://oestrangeiro.org/2020/05/05/organizacoes-semobilizam-na-doacao-de-cestas-basicas-para-imigrantes-erefugiados-durante-a-pandemia-da-covid-19/ Acesso em: 19 de maio de 2020
} 
inclusiva a fim de que os migrantes sejam vistos e sintam-se agente ativos na sociedade, e com isso, possam recuperar sua cidadania, sua identidade que muitas vezes é perdida em face do processo migratório.

\section{Considerações finais}

O presente artigo buscou demonstrar a ausência de proteção social por parte do Estado brasileiro aos migrantes no contexto da pandemia da Covid-19 por meio da objeção do acesso ao benefício assistencial do auxílio emergencial. Para isso, abordou-se à proteção normativa dos migrantes para demonstrar a qualidade de sujeitos de direito e titulares de garantias fundamentais no Brasil em condições de igualdade em relação aos direitos conferidos aos brasileiros, desde a Declaração dos Direitos Humanos até a Lei 13.445/2017, Lei de Migração.

Em seguida, contextualiza-se sua condição social com o atual fenômeno que os cercam, a pandemia da Covid-19, de modo a expor o dever de proteção social estatal com enfoque no direito à assistência social. Por fim, aborda-se a ausência de proteção social no dever de assegurar o direito ao benefício assistencial do auxílio emergencial ao grupo, suas causas e efeitos à pessoa migrante.

Conclui-se pela displicência por parte do Estado brasileiro para com seu dever de proteção social ao grupo frente a documentos internacionais ratificados, à legislação nacional e à agenda mundial da ONU composta pelos Objetivos de Desenvolvimento Sustentável (ODS). Considera-se injustiça social a objeção do direito ao benefício que culmina numa série de efeitos negativos que atingem os migrantes, pois compromete o mínimo existencial, os expõe à condições desumanas e ilegais, além de violar o direito fundamental à assistência social e ofender a dignidade da pessoa humana.

Os efeitos recaem tanto no âmbito econômico, quanto no âmbito moral, além de contribuir para o aumento da desigualdade social no país. Demonstrou-se que a displicência estatal deriva de motivos que vão desde a globalização da indiferença, de vislumbrar o migrante como uma pessoa estranha ao território e achar que o problema não é do país, de um Estado regulador da atividade econômica que se vincula a possibilidades orçamentária e recua no dever de proteção social de efetivar direitos sociais, até por tratar-se de um direito que busca a consolidação ainda sob o manto da caridade e da filantropia, ou seja, do favor.

Propõe-se o acesso e o saque do benefício mencionado de forma facilitada mediante apresentação de qualquer documentação a que possuam, mesmo com prazo de validade expirado e sem exigência 
de foto. Sugere-se uma orientação às agências pagadoras para que o atendimento aos migrantes ocorra de forma padronizada, haja vista que cada agência atua de forma diferenciada no tocante à exigência da documentação para o pagamento do benefício.

Almeja-se, portanto, uma proteção social de inclusão que embasa-se nas ideias de justiça social focada em realizações, conforme discurso de Amartya Sen, a qual transcende a teoria de Justiça contratualista de Jonh Rawls que, para Sen, é focada em arranjos institucionais. Pretende-se, portanto, uma proteção social inclusiva que ultrapasse o caráter assistencialista para o fim de tornar o migrante agente ativo na sociedade e com isso possa desenvolver suas próprias capacidades, na busca de um patamar civilizatório de bem estar social, em prol de um desenvolvimento humano que se alinhe ao crescimento econômico do país.

\section{Referências}

AGAMBEN, Giogio. Infância e História: destruição da experiência e origem da história. Tradução Henrique Burigo. Belo Horizonte: Editora UFMG, 2008.

ALEXY, Robert. Teoria dos Direitos Fundamentais. Tradução de Virgílio. Afonso da Silva. São Paulo: Malheiros, 2008.
ARENDT, Hannah. Origens do totalitarismo. São Paulo: Companhia das Letras, 2012.

JUBILUT, Liliana Lira e OLIVEIRA Selmi Apolinário, SM (2008). Determinação do status de refugiado no Brasil: uma empresa tripartida. Refúgio: Jornal do Canadá sobre Refugiados. p. 29-40. Disponível em: https://refuge.journals.yorku.ca/index.php/ref uge/article/view/26029. Acesso em: 23 de abril de 2020.

BARRETO, Luiz Paulo Teles Ferreira. A Lei Brasileira de Refúgio - Sua história. p. 12 - 21. In: Refúgio no Brasil: a proteção brasileira aos refugiados e seu impacto nas Américas. Brasília: ACNUR, Ministério da Justiça, 2010.

BAUMAN. Zigmunt. Extanhos ilamando a la puerta. Disponível em: file:///C:/Users/Usuario/Desktop/Disserta\%C 3\%A7\%C3\%A3o/34082_Extranos_llamand o_a_la_puerta.pdf. Acesso em: 20 de maio de 2020.

BELLO, Enzo; BERCOVIC, Gilberto; LIMA, Martonio Mont'Alverne Barreto. O fim das ilusões constitucionais de 1988 ? Revista Direito e Práxis, Rio de Janeiro, v. 10, n. 3, p. 1769-1811, 2019. Disponível em: https://www.e-

publicacoes.uerj.br/index.php/revistaceaju/ar ticle/view/37470. Acesso em: 20 maio 2020. DOI: $10.1590 / 2179-8966 / 2018 / 37470$.

CASTEL, Robert. A insegurança social. O que é ser protegido? Tradução de Lúcia M. Endlich Orth. Petrópolis: Editora Vozes, 2005.

CHAVES, Victor Pinto. O direito à assistência social no Brasil. Elsevier. 2013.

COMPARATO, Fábio Konder. A afirmação histórica dos direitos humanos. $7^{\mathrm{a}}$ edição. São Paulo: Saraiva, 2010. 
COUTO, Maria Berenice. Assistência social ou benesse? Serviço Social \& Sociedade. 2015, n.124. p.665-677.

HOBBES, Thomas. Leviatã. Matéria, forma e poder de um Estado eclesiástico e civil. Tradução de João Paulo Monteiro e Maria Beatriz Nizza da Silva. 3. ed. São Paulo: Abril Cultural, 1983. Col. Os Pensadores.

HOLMES, S.et SUSTEIN, C. The Cost of Rights. Why liberty depends on taxes. Ne York: W.W. Norton and Company, 1999.

HONNET, Axel. Sofrimento de indeterminação: uma atualização da filosofia do direito de Hegel.São Paulo: Editora Singular, Esfera Pública, 2007.

HUNT, Linn. A invenção dos direitos humanos: Uma história. Tradução: Rosaura Eichenberg ed. Companhia das Letras. 2007.

IGREJA, R. L.; CAMACHO, M. T. S.; DANTAS, F. A. DE C.; RAMPIN, T. T. D. Contribuições das ciências sociais diante $\mathrm{o}$ avanço do neoliberalismo. Abya-yala: Revista sobre Acesso à Justiça e Direitos nas Américas, v. 2, n. 1, p. 1-6, 30 abr. 2018.

JUBILUT, Liliana Lyra. O direito internacional dos refugiados e sua aplicação no ordenamento jurídico brasileiro. São Paulo: Método, 2007.

LASSALLE, Ferdinand. A essência da Constituição. $6^{\text {a }}$ Ed. Rio de Janeiro, Lumen Juris, 6 ${ }^{\text {a Ed. }} 2001$.

MORRISON, Wayne. Filosofia do Direito: dos Gregos ao Pós-Modernismo. São Paulo: Martins Fontes, 2006. P.472-473.

NUSSBAUM, Martha. Fronteiras da Justiça: deficiência, nacionalidade, pertencimento à espécie. São Paulo: Martins Fontes, 2013.

OLSEN, Ana Carolina Lopes. A eficácia dos direitos fundamentais sociais frente à reserva do possível. Dissertação (mestrado).

Curitiba: UFPR, 2006.
PANSIERI. Flávio. A Crítica de Amartya Sen à concepção Rawlsiana de Justiça, p. 126. 2016. Disponível em: https://www.scielo.br/pdf/seq/n74/01019562-seq-74-00181.pdf. Acesso em: 20 de maio de 2020.

POMPEU, GINA et.al. Estado social, Desenvolvimento Humano e

Sustentabilidade na América Latina. In: Direitos Fundamentais na perspectiva da Democracia Interamericana. Lumen Juris, p. 225-256. 2019.

\section{RAMOS, Elival da Silva. CONTROLE} JURISDICIONAL DE POLÍTICAS PÚBLICAS: a efetivação dos direitos sociais à luz da Constituição brasileira de 1988 in: Revista da Faculdade de Direito da Universidade de São Paulo v. 102 p. 327 356. 2007.

RAWLS, John. Uma Teoria da Justiça. Tradução Almiro Pisetta e Lenita M.R. Esteves. 3. ed. São Paulo: Martins Fontes, 2008.

SANTOS, Boaventura de Sousa. A gramática do tempo para uma nova cultura política. 3. ed. São Paulo: Cortez, 2010.

SEN, Amartya. Desigualdade reexaminada. Tradução de Ricardo Doninelli Mendes. Rio de Janeiro: Record, 2008.

SEN, Amartya. A Ideia de Justiça. São Paulo: Companhia das Letras, 2011.

SEN, Amartya. O desenvolvimento como liberdade; São Paulo; Companhia das Letras, 2010 .

YAZBECK, Maria Carmelita. As ambiguidades da assistência social brasileira após dez anos de Loas. Serviço Social \& Sociedade, São Paulo, ano XXV, n. 77, mar. 2014.

ZAMBAM, Neuro José; KUJAWA, Henrique Aniceto. As políticas públicas em Amartya Sen: condição de agente e liberdade 
social/Public policies in Amartya Sen: agent condition and social freedom. Revista

Brasileira de Direito, Passo Fundo, v. 13, n.

1, p. 60-85, mar. 2017. ISSN 2238-0604.

Disponível em:

https://seer.imed.edu.br/index.php/revistaded ireito/article/view/1486.

doi:https://doi.org/10.18256/2238-

0604/revistadedireito.v13. n1, p 60-85.

Acesso em: 21 maio 2020. 